\title{
Dying of VOC-202012/01 - multimodal investigations in a death case of the SARS-CoV-2 variant
}

\author{
Fabian Heinrich $^{1}$ (D) - Carina Romich ${ }^{1} \cdot$ Tamara Zimmermann $^{1} \cdot$ Inga Kniep $^{1} \cdot$ Antonia Fitzek $^{1} \cdot$ Stefan Steurer $^{2}$. \\ Markus Glatzel $^{3}$ · Dominik Nörz ${ }^{4}$. Thomas Günther ${ }^{5} \cdot$ Manja Czech-Sioli $^{4} \cdot$ Nicole Fischer $^{4}$ - Adam Grundhoff ${ }^{5}$. \\ Marc Lütgehetmann ${ }^{4}$. Benjamin Ondruschka ${ }^{1}$
}

Received: 1 March 2021 / Accepted: 28 April 2021 / Published online: 5 June 2021

(c) The Author(s) 2021

\begin{abstract}
The current pandemic with Severe acute respiratory syndrome-coronavirus-2 has been taking on new dynamics since the emergence of new variants last fall, some of them spreading more rapidly. Many countries currently find themselves in a race to ramp up vaccination strategies that have been initiated and a possible third wave of the pandemic from new variants, such as the Variant of Concern-202012/01 from the B.1.1.7 lineage. Until today, many investigations in death cases of Coronavirus-disease-19 have been conducted, revealing pulmonary damage to be the predominant feature of the disease. Thereby, different degrees of macroscopic and microscopic lung damage have been reported, most of them resembling an Acute Respiratory Distress Syndrome. Far more, systemic complications of the disease such as pulmonary embolisms have been described. However, neither morphologic nor virologic findings of patients dying of the new variants have yet been reported. Here, we report on a comprehensive analysis of radiologic, morphologic, and virologic findings in a fatal case of this variant.
\end{abstract}

Keywords SARS-CoV-2 · Variant of Concern-202012/01 · B.1.1.7 · 501Y.V1 · Postmortem · Coronavirus-disease-19 . Respiratory infections

Marc Lütgehetmann and Benjamin Ondruschka equally contributed last authorship.

Fabian Heinrich

fa.heinrich@uke.de

1 Institute of Legal Medicine, University Medical Center Hamburg-Eppendorf, Butenfeld 34, 22529 Hamburg, Germany

2 Institute of Pathology, University Medical Center Hamburg-Eppendorf, Hamburg, Germany

3 Institute of Neuropathology, University Medical Center Hamburg-Eppendorf, Hamburg, Germany

4 Institute of Medical Microbiology, Virology and Hygiene, University Medical Center Hamburg-Eppendorf, Hamburg, Germany

5 Heinrich-Pette-Institute, Leibniz-Institute for Experimental Virology, Hamburg, Germany

\section{Introduction}

On March 12, 2020, the World Health Organization declared Severe acute respiratory syndrome-coronavirus-2 (SARS$\mathrm{CoV}-2$ ) and Coronavirus-disease-19 (COVID-19) to be a pandemic [1]. Since 2.5 million people died of the novel pathogen, and case fatality rates ranging from 0.7 to $7.2 \%$ have been reported [2-4]. Fatal outcomes of the disease were mainly attributed to respiratory failure by Acute Respiratory Distress Syndrome (ARDS) [5]. In line with this, different degrees of macroscopic and microscopic lung damage have been described in deceased of COVID-19 [6-8]. In particular, the microscopic damage constitutes diffuse alveolar damage with hyaline membranes. Simultaneously, systemic complications of the disease were suggested at an early stage of the pandemic: Coagulopathy and thromboembolic complications have consistently been reported in COVID-19 patients alive and death $[9,10]$.

While the characteristics and pathomechanisms of the disease are becoming more and more understood, new variants of SARS-CoV-2 are emerging all over the world [11]. 
One of these emerged in the Region of Kent (United Kingdom) and is defined by 23 characteristic mutations [12]. This new variant gained international attention when epidemiologic data on spread dynamics were first published [13]. Preliminary data suggest this variant to spread more effectively compared to previously circulating lineages [13]. An explanation could be a mutation, N501Y, in the receptorbinding domain of the spike protein, which is important for cellular entry [14]. Other explanations include prolonged viral shedding [15]. Therefore, and due to the possibility of higher mortality rates reported in preliminary reports, concerns have been raised on this new variant [16].

Further analyses successfully confirmed the new variant to spread more effectively [17]. Whether the course of the disease is more severe and ultimately deadly remains to be determined. As of today, autopsy data on disease-specific findings in patients dying of the new variant are missing. Here, we report on detailed radiologic, morphologic, and virologic findings in a fatal case of this new variant (B.1.1.7/Variant-of-concern-202012/01 [VOC-202012/01]).

\section{Methods}

\section{Postmortem computed tomography}

Philips Brilliance 16-slice MDCT was used for a wholebody scan (slice thickness $1 \mathrm{~mm}$, Pitch 1.5, $120 \mathrm{kV}, 230-250$ $\mathrm{mAs}$ ). The thorax was additionally scanned using higher resolutions (slice thickness $0.8 \mathrm{~mm}$, Pitch $1.0,120 \mathrm{kV}$, 230-250 mAs).

\section{External and internal examination}

External and internal corpse examination were performed in accordance with guidelines on the forensic full postmortem examination by the German Society of Legal Medicine (AWMF 054/001) [18]. Special consideration of recent guidelines on the handling of COVID-19 deaths has been made [19]. Photographic and written documentation was performed thoroughly.

\section{Histology}

Tissues were fixed in formalin for $24 \mathrm{~h}$ and subsequently embedded in paraffin. Hereafter, hematoxylin and eosin (H.\&E.) stainings were performed using a Ventana Benchmark XT automated staining system. Additionally, immunohistochemical stainings were performed for B- and T-lymphocytes in the lungs, as well as for activated astrocytes, and activated microglia in the frontal cortex using antibodies directed against the human glial fibrillary acidic protein (GFAP) (clone 6F2; Dako, Glostrup, Denmark; dilution
1:200) and HLA-DR (clone CR3/43; Dako, Glostrup, Denmark; dilution 1:200). Slides were examined by experienced pathologists and neuropathologists (S.S. and M.G.) and were electronically scanned at high magnification $(\times 40)$ as highresolution images $(1900 \times 1200$ pixels $)$ with a NanoZoomer 2.0-HT (Hamamatsu Photonics, Hamamatsu, Japan).

\section{Virology}

\section{RT-PCR for SARS-CoV-2}

Nasopharyngeal swabs withdrawal and analysis for SARSCoV-2 RNA were performed as recently described [20]. Reverse-transcription quantitative polymerase chain reaction (RT-qPCR) for N501Y and del HV69/70 as described elsewhere in a combination with commercially available assays screening for E484K and P681H (TIB Molbiol, Berlin, Germany) as recommended by the manufacturer was additionally done to screen for the VOC-202012/01 lineage [21].

For further analysis, native tissue samples and bodily fluids were obtained during the conventional autopsy. Tissue samples of $1 \mathrm{~cm}^{3}$ were taken using different scalpels and petri-dishes and bodily fluids by using different syringes and cannulas. The specimens were immediately processed and analyzed for the E-gene of SARS-CoV-2 by RT-qPCR [22]. For quantification, standard in vitro-transcribed RNA of the E gene of $S A R S-C o V-2$ was used. The human B-globin gene was quantified by PCR (Life technologies, Thermo Fischer, USA) and used for normalization of viral RNA loads.

\section{SARS-CoV-2 whole-genome sequencing and bioinformatics analysis}

Viral genome sequencing was carried out as recently published $[23,24]$ with the following modifications: Amplicon sequencing and sequencing library generation were performed using the CleanPlex SARS-CoV-2 Panel (Paragon Genomics, CA, USA). Samples were sequenced on Illumina MiSeq using a 300 cycle MiSeq v2 reagent kit (Illumina, CA, USA). Quality-filtered paired-end amplicon sequencing reads were trimmed for Illumina sequencing adapters as well as correct amplicon primer pair sequences. Reads were then merged and subsequently aligned to NC_045512.2 using minimap2 [25] with default settings for short read alignment. Variants were called using freebayes Bayesian haplotype caller v 1.3.1 [26] with ploidy and haplotype-independent detection parameters to generate frequency-based calls for all variants passing input thresholds (-K $-\mathrm{F} 0.5)$. Input thresholds were set to at least 10 variant supporting reads with a minimum base quality of 30 (-C10 -q30). Only high confidence variants present in $\geq 50 \%$ of reads were included and annotated using ANNOVAR [27]. 


\section{Case report}

We report on a 70-year-old woman who presented to the emergency service in an unconsciousness, asystole state. Cardiopulmonary resuscitation was performed using manual chest compression and high doses of catecholamines without return of spontaneous circulation. Then, the patient was declared dead. The onsite case evaluation revealed that the patient got up confused in the middle of the night and has fallen to the floor unconscious. Her husband reported no other symptoms prior to death. Only routine RT-qPCR screenings at the Institute of Legal Medicine revealed an infection with the novel variant of SARS-CoV-2. In accordance with the German infection protection law, the public health authorities were informed immediately.

The retrospective case evaluation by the emergency services, public health authorities, and the Institute of Legal Medicine revealed that the woman in fact became to feel sick 3 days prior to death. She started coughing, and the following night, she developed a fever with heavy sweating. No myalgia, headache, or dyspnea was reported. Her general condition continued to deteriorate until she presents unconscious. However, no possible transmission event could be evaluated.

Individual risk factors were evaluated from the patient's medical records. Relevant pre-existing diseases were arterial hypertension, bronchial asthma, coronary heart disease, and chronic kidney disease. Furthermore, an adrenal adenoma was reported.

\section{Postmortem computed tomography}

The lungs showed bilateral diffuse to global consolidation with a focus to the centrilobular areas. Reticular changes with peripheral accentuation can be found in both lungs.

Also, scattered ground glass opacities were found with a focus to the dorsal lung areas. In accordance, with resuscitation procedures, serial rib fractures were found. Additionally, general and coronary atherosclerosis to moderate degrees, cardiac hypertrophy, and minutely atrophic kidneys were detected.

\section{Findings of the autopsy and histology}

The 70-year-old woman presents over-weighted (BMI: $29.5 \mathrm{~kg} / \mathrm{m}^{2}$ ) without external or internal signs of trauma despite chest compression-related rib fractures and bleedings.

A full autopsy has been performed. Examining the lungs, we found hyperaemic areas of more dense consistency with a particular focus on the centrilobular regions of both lungs and some subpleural hemorrhages (Fig. 1a-d). Minimal pleural effusions (right side: $50 \mathrm{ml}$, left side: $50 \mathrm{ml}$ ) and an intra-alveolar lung oedema accompanied the observed inflammatory processes (Fig. 2d, e). The latter resulted in a lung weight of $1500 \mathrm{~g}$ in total (right lung lobe: $855 \mathrm{~g}$, left lung lobe: $645 \mathrm{~g}$ ). Detailed histologic examination revealed inflammatory changes with a focus on the central areas of both lungs. More precisely, lymphocytic cell infiltration predominantly consisting of CD8 positive cells was found within the interstitial lung areas (Fig. 2e). Local aggregation of CD8 positive cells within the alveoli was found. Disseminated spots of activated type II pneumocytes were observed, and hyaline membranes and the presence of microthrombi within the lungs accompany the reported findings (Fig. 2a, c). Also, hemorrhagic alveolar infiltration was found (Fig. 2b), and mediastinal lymph nodes showed reactive hyperplasia. Concurring inflammatory changes in the lungs, morphological signs of systemic inflammation were found in terms of "septic spleen" and lipid depletion of the adrenal glands.

Interestingly, we also found peripheral pulmonary embolisms (PE) involving the segmental (in the left pulmonary artery flow area) and sub-segmental vessels (in the right pulmonary artery flow area) in this case. The latter presented slightly ribbed without adhering to the vessel wall. Accordingly, deep vein thrombosis (DVT) in the leg veins was found without adherence of the thrombi to the vessel walls (Fig. 1e). The blood in the heart chambers and large vessels presented fluid.

Neuropathologic examinations of the brain showed astrogliosis pronounced around vessels and mild-to-moderate activation of microglia, with occasional microglial nodules (Fig. 2f-g). There were no signs of fulminant potentially virus-induced encephalitis, and there was no evidence of cerebral bleeding or small-vessel thromboses.

Apart from the signs of the diseases previously diagnosed, other organs showed no significant macroscopic or microscopic changes.

\section{Virologic examination}

The initial virologic assessment revealed high nasopharyngeal loads of the SARS-CoV-2 E-gene with $3.3 \times 10^{8}$ RNA copies/ml. Typing assays for VOC-202012/01 revealed positive results for $\mathrm{N} 501 \mathrm{Y}$ and $\mathrm{P} 681 \mathrm{H}$ but not for E484K, thereby successfully confirming the typical characteristics of VOC-202012/01.

These results were underlined by the results of amplicon sequencing; thereby confirming the assignment to the B.1.1.7 pangolin lineage with its typical deletions and point mutations in the S-gene and other viral genome regions (Fig. 3a). In addition to the described core mutations of VOC-202012/01, the sequence contains two mutations in orf 1ab: one synonymous mutation in the nsp2 gene, nucleotide (nt) position 2623 , and one non-synonymous mutation 

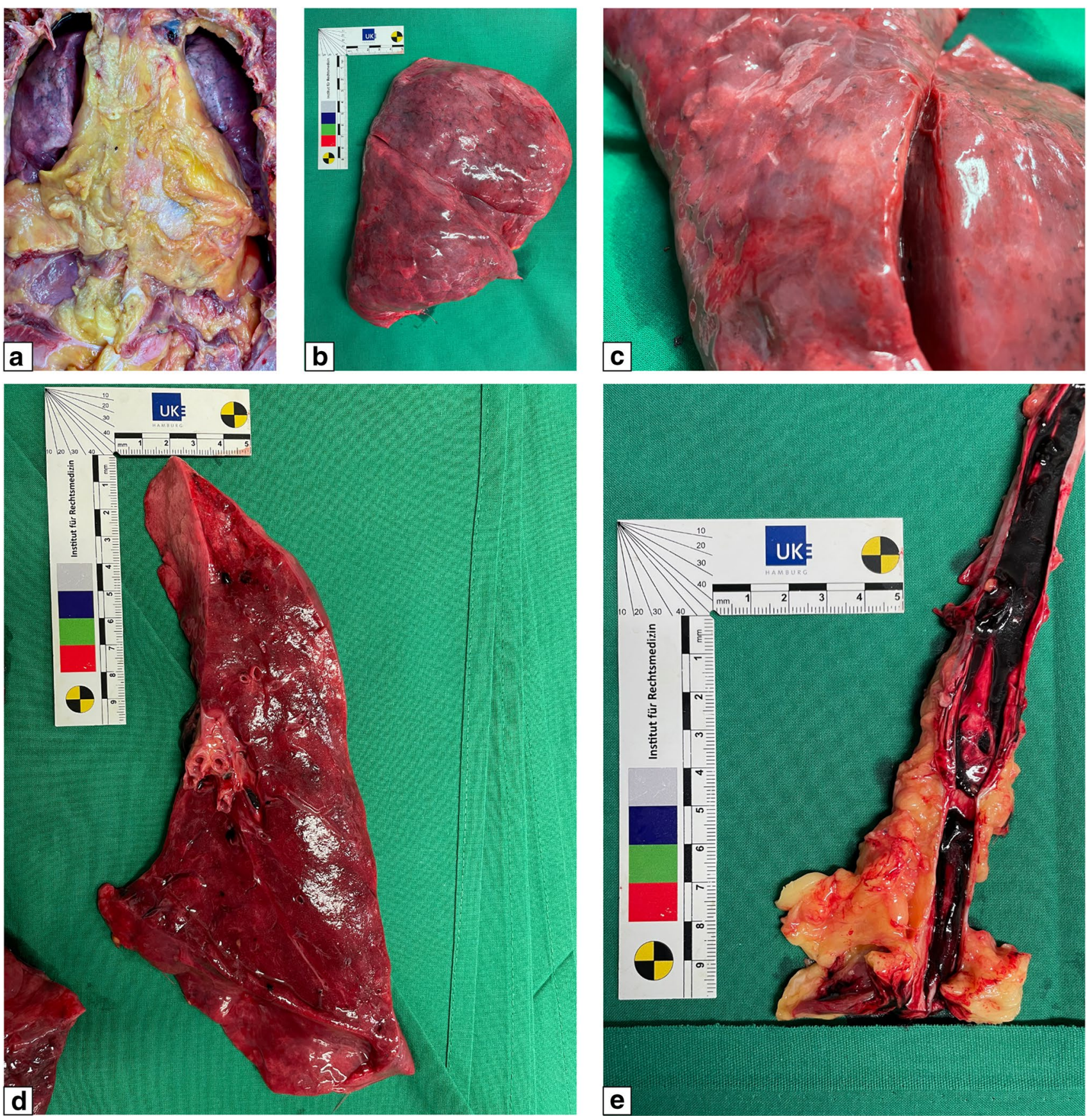

Fig. 1 Macroscopic findings during the autopsy. An overview of the chest cavity (a) and more detailed pictures of the surface and crosssections of the lungs (b-d) illustrating bilateral deep red hyperemic

in the nsp3 gene, encoding the papain like protease. The single nucleotide polymorphism (SNP) at nt 5762 , results in an amino acid (aa) change at position 1833 from cysteine to the basic aa arginine. This genotype has been described previously in sequences entered in the GISAID database [28] sampled in Germany, Schleswig-Holstein, and Denmark (Fig. 3b). discolorations with peripheral hyper-inflation of the lungs. Exemplary deep venous thromboses of the femoral vein are illustrated (e)

Furthermore, we examined the presence of SARS-CoV-2 RNA in a comprehensive collection of different tissues and bodily fluids (Fig. 4). Thereby, viral RNA was detected in virtually all tissues and bodily fluids analyzed. In femoral venous blood, $1.17 \times 10^{5} S A R S$ - $C o V-2$ RNA copies per milliliter were detected. Titres exceeding the viral load in the blood are marked in red (Fig. 4). 

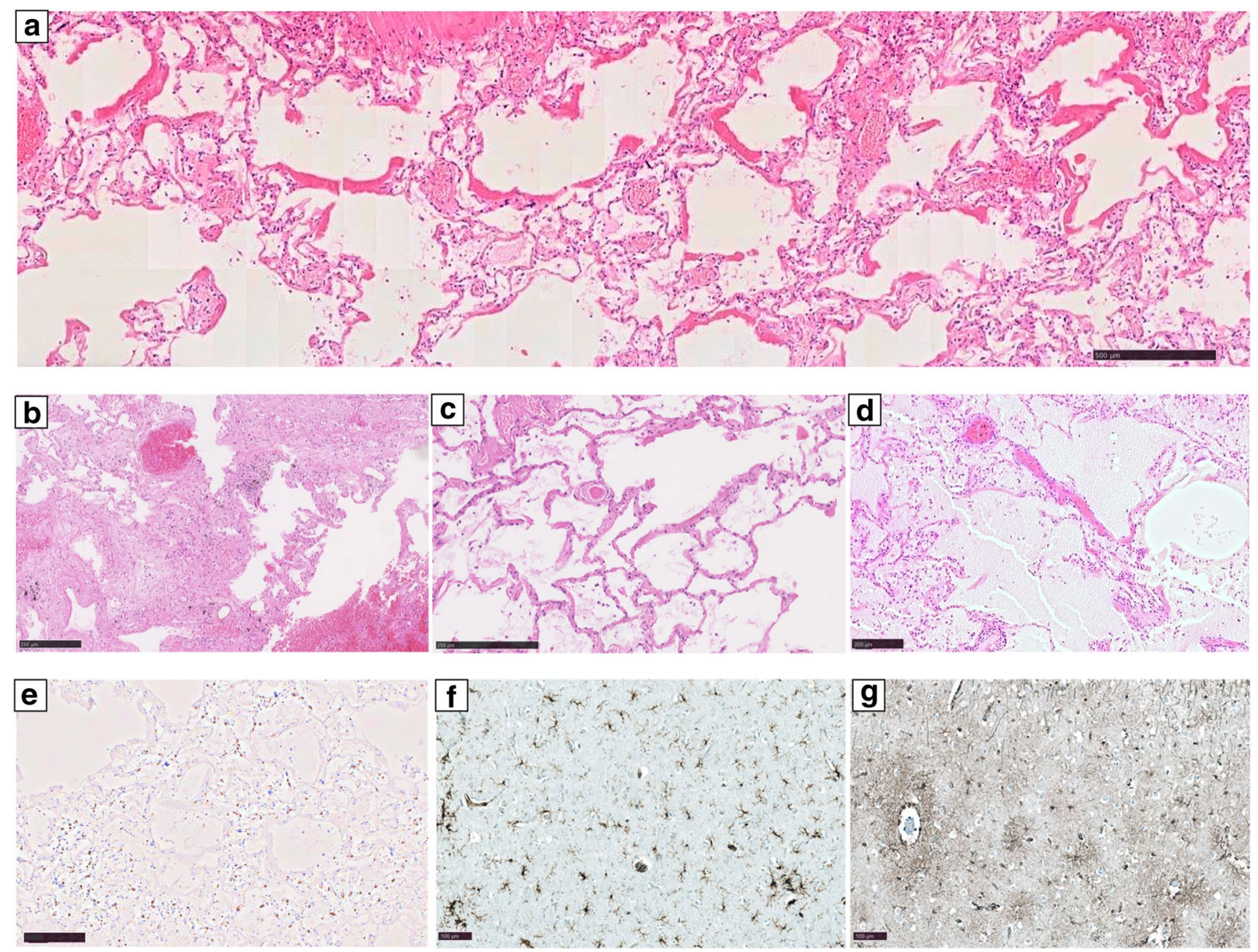

Fig. 2 Microscopic findings of the histologic examination. The lungs of the deceased showed signs of diffuse alveolar damage with hyaline membranes (a), hemorrhagic interstitial and alveolar infiltration (b), the presence of microthrombi (c), and an intra-alveolar oedema (d) (H.\&E.). Interstitial accumulation of CD8 positive cells (anti-CD8

Matching high viral titres in the nasopharynx, we found high viral loads in the upper respiratory tract (i.e., olfactory mucosa, and trachea) and both lung lobes (Fig. 4). Also, stomach contents were tested highly positive for SARS-CoV-2 RNA (71.49 copies/cell). Of note, not only the vagus nerve but also the common carotid artery being part of the para-pharyngeal space show high amounts of SARS-CoV-2 RNA (N. vagus: 340.14 copies/cell, A. carotis communis: 13.91 copies/cell). In the bodily fluids tested, such as urine and cerebrospinal fluid (CSF), low viral loads were shown (urine: 1.65 copies/cell, CSF: 0.37 copies/cell).

\section{Discussion}

Here, we report on a 70-year-old woman dying of COVID-19 due to a new variant of SARS-CoV-2 (B.1.1.7/VOC-202012/01). antibody) was found in the central areas of both lungs (e). Perivascular astrogliosis (anti-glial fibrillary acidic protein antibody) and mild-to-moderate activation of microglia, with occasional microglial nodules in the frontal cortex (anti-HLA-DR antibody) (f-g). Picture specific scale bars are shown

In the postmortem computed tomography, ground glass opacities and reticular changes of both lungs have been described as being COVID-19-associated lung changes [29]. These are also the radiological characteristics that we were able to identify in this case. However, the observed radiologic findings are reported to be not disease-specific [29]. Apart from previously described changes in the literature, no other pulmonary radiologic features were observed [29].

In line with recent reports, hemorrhagic alveolar infiltration was found being a typical autoptic sign of viral pneumonia [30]. Far more, macroscopic findings of heavy lungs and microscopic findings of intra-alveolar oedema, hyaline membranes, and microthrombi quite appropriately illustrate the early stages undergoing an Acute Respiratory Distress Syndrome (ARDS) as frequently reported in COVID-19 patients [6-8]. 
a

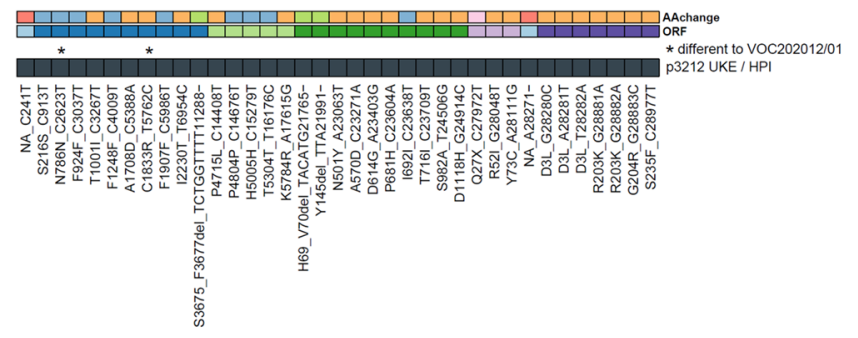

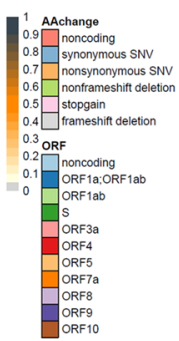

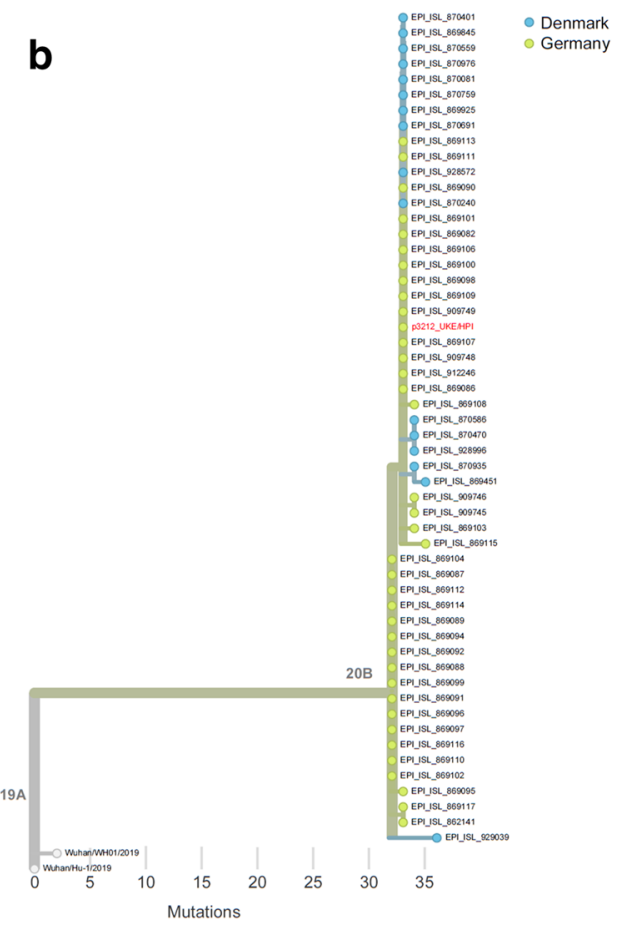

in-the-uk-defined-by-a-novel-set-of-spike-mutations/563). Additional variant positions present in p3212_UKE/HPI are marked with an asterisk. b Phylogenetic analysis of p3212_UKE/HPI sample within the context of B.1.1.7 isolates. Samples were analyzed and visualized within the phylogenetic context by next strain (nextstrain.org) using data available through GISAID (gisaid.org); GISAID identifiers are indicated at the right. Shown are only closely related sequences with 4 nucleotide substitution difference from the sequence p3212_UKE/ HPI (in red). Sequences sampled in Germany, Schleswig-Holstein, are shown in green, while sequences from Denmark are in blue

system supports the view that disease-associated neuroinflammation may contribute to neurologic deficits seen in COVID-19 patients [36].

The other macroscopic and microscopic findings observed represent changes associated with the patient's pre-existing medical conditions and older age. Interestingly, most of the pre-existing conditions, namely arterial hypertension, coronary heart disease, and chronic kidney disease, have been shown to be associated with severe and/or fatal courses of COVID-19 [37]. Thus, the patient was particularly susceptible to a severe and fatal course of the disease. Beyond that, all virus-related macroscopic and microscopic findings are similar to those of several reports on autopsy findings in COVID-19 decedents from a variety of authors all over the world. No surprising potentially lineage-specific morphologic findings were documented.

Virologic examinations reveal high viral loads in the nasopharynx of the deceased, indicative of an acute course of COVID-19 [38]. The trachea and lungs of the deceased were also highly positive, matching the pulmonary tropism of the virus. In line with the latest findings of Meinhardt et al., the olfactory mucosa was also affected by the virus [39]. Positive 


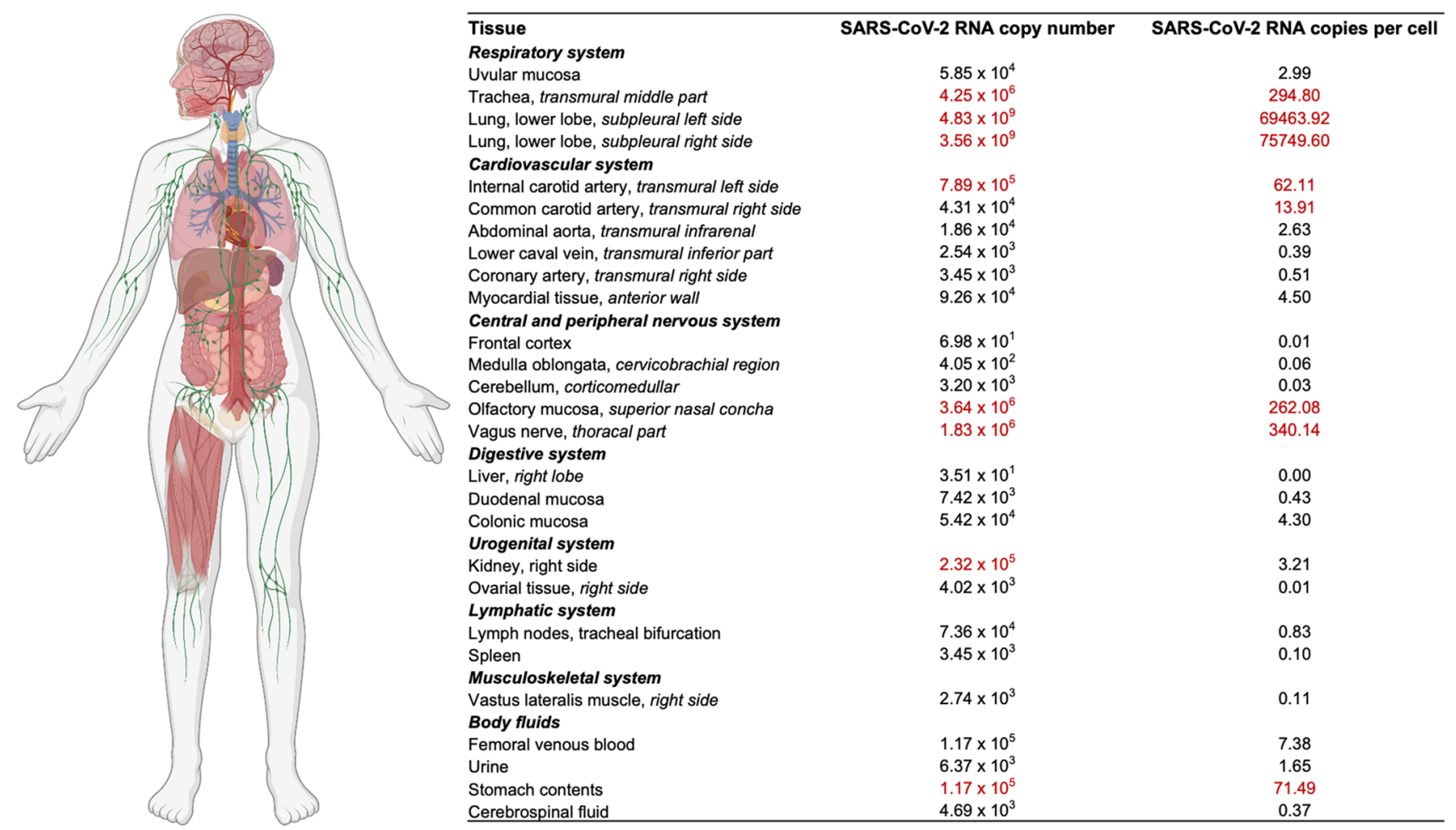

Fig. 4 Distribution of SARS-CoV-2 RNA loads in different tissues and bodily fluids. Real time-quantitative polymerase chain reaction has been performed from separately taken tissues and bodily fluids. Quantified SARS-CoV-2 RNA copy numbers (E-gene) are shown

stomach contents could be explained by ingestion of virus particles into the stomach. An explanation for the highly positive testing of the vagus nerve and carotid artery could result from the spatial proximity to the pharyngeal space. Also known as "Danger space," bacterial spread has been described in these regions [40]. It is worth noting that all tissues tested were positive for SARS-CoV-2 RNA. While cross-contamination during the autopsy was excluded by separate surgical instruments, dissemination of viral RNA by the patient's viremia cannot be excluded. Whether tissues with RNA levels exceeding those of blood represent sites of active viral replication or accumulation of viral RNA needs further studies. It was shown that the N501Y mutation leads to an increased affinity to the ACE2 receptor. This might lead to an altered organtropism. However, the RNA tropisms observed here do not differ to the N501 wildtype. Further studies are needed to find potential correlates of increased mortality, i.e., altered or enhanced organ tropisms.

Important to mention here is the added value of postmortem screenings for SARS-CoV-2. At the point of death of the patient, first reports on the new variant in Germany have been made [41]. Ad-hoc analyses by the Robert Koch Institute from the week after this death case revealed B.1.1.7 positivity in 5.8\% of all nationwide screened cases [42]. The incidental finding of SARS-CoV-2 in this case, e.g., might be indicative of a previously unknown per milliliter and normalized per cell. Viral copy numbers exceeding those of blood are marked in red. This figure was created with BioRender.com

cluster of VOC-202012/01 infections. Following this insight, the health authorities have traced contacts of all persons involved and ordered a quarantine. Therefore, this case not only underlines the importance of such screenings for questions relevant to occupational safety but also emphasizes its importance for infection control purposes. The potential of next-generation sequencing in postmortem applications is highlighted.

Acknowledgements We would like to thank Ms. Philine Lange and Ms. Jessica Vering for their excellent and skillful technical support. We thank Daniela Indenbirken, Kerstin Reumann, and Christina Herrde for technical support with NGS library preparation. Also, we would like to offer condolences to the family and friends of the deceased.

Author contribution Drafting of the article: F. Heinrich, N. Fischer, M. Lütgehetmann, B. Ondruschka. Provision of study materials: F. Heinrich, C. Romich, T. Zimmermann, A. Fitzek, B. Ondruschka. Collection and assembly of patient data: F. Heinrich, B. Ondruschka. Contribution and interpretation of radiological data: I. Kniep, B. Ondruschka. Contribution and interpretation of histological data: S. Steurer, M. Glatzel, B. Ondruschka. Contribution and interpretation of virological data: D. Nörz, T. Günther, M. Czech-Sioli, N. Fischer, A. Grundhoff. Administrative, technical, or logistic support: F. Heinrich, C. Romich, T. Zimmermann, A. Fitzek, S. Steurer, M. Glatzel, D. Nörz. T. Günther, M. Czech-Sioli, N. Fischer, A. Grundhoff, M. Lütgehetmann, B. Ondruschka. Critical revision for important intellectual content: F. Heinrich, S. Steurer, M. Glatzel, T. Günther, N. Fischer, M. Lütgehetmann, B. Ondruschka. Final approval of the article: F. 
Heinrich, C. Romich, T. Zimmermann, I. Kniep, A. Fitzek, S. Steurer, M. Glatzel, D. Nörz, T. Günther, M. Czech-Sioli, N. Fischer, A. Grundhoff, M. Lütgehetmann, B. Ondruschka. Obtaining of funding: B. Ondruschka.

Funding Open Access funding enabled and organized by Projekt DEAL. This case report was created within the framework of the DEFEAT PANDEMIcs project, funded by the Federal Ministry of Education and Research (BMBF) under the grant number 01KX2021. Parts of this study were funded by the support of the Ministry of Labour, Health, Family Affairs and Integration (Hamburg). The funders had no role in study design and conduct; data collection, management, analysis, and interpretation; and approval, review or preparation, and decision to publish the manuscript.

Data availability Not applicable.

Code availability Not applicable.

\section{Declarations}

Ethics approval The Ethics Committee of the Hamburg Chamber of Physicians approved the study (No.: PV7311).

Consent to participate The family of the deceased declared their informed consent for examination of the deceased and for the publication of our findings according to the presumed will of the deceased.

Consent for publication The family of the deceased declared their informed consent for examination of the deceased and for the publication of our findings according to the presumed will of the deceased.

Conflict of interest Dr. Ondruschka, Dr. Lütgehetmann, Dr. Fischer, and Dr. Grundhoff report grants and other within the framework of the DEFEAT PANDEMICs project by the Federal Ministry of Education and Research (BMBF) under the grant number 01KX2021. Dr. Fischer and Dr. Grundhoff report grants and other from the Ministry of Labour, Health, Family Affairs and Integration (Hamburg). Mr. Heinrich, Ms. Romich, Ms. Zimmermann, Dr. Kniep, Dr. Fitzek, and Dr. Ondruschka further report grants and other from the Authorities for Social Welfare, Hamburg, Germany. Dr. Glatzel and Dr. Nörz have nothing to disclose.

Open Access This article is licensed under a Creative Commons Attribution 4.0 International License, which permits use, sharing, adaptation, distribution and reproduction in any medium or format, as long as you give appropriate credit to the original author(s) and the source, provide a link to the Creative Commons licence, and indicate if changes were made. The images or other third party material in this article are included in the article's Creative Commons licence, unless indicated otherwise in a credit line to the material. If material is not included in the article's Creative Commons licence and your intended use is not permitted by statutory regulation or exceeds the permitted use, you will need to obtain permission directly from the copyright holder. To view a copy of this licence, visit http://creativecommons.org/licenses/by/4.0/.

\section{References}

1. World Health Organization (2020) Coronavirus disease 2019 (COVID-19) Situation Report - 51. https://apps.who.int/iris/bitst ream/handle/10665/331475/nCoVsitrep11Mar2020-eng.pdf? sequence $=1 \&$ isAllowed $=y$. Accessed 21.02.2021
2. Johns Hopkins University (2021) Johns Hopkins Coronavirus Resource Center. https://coronavirus.jhu.edu/map.html. Accessed 21.02.2021

3. Onder G, Rezza G, Brusaferro S (2020) Case-fatality rate and characteristics of patients dying in relation to COVID-19 in Italy. JAMA 323(18):1775-1776. https://doi.org/10.1001/jama.2020. 4683

4. Wang X, Ma Z, Ning Y, Chen C, Chen R, Chen Q, Zhang H, Li C, He Y, Wang T, Tong C, Wu J, Li Y, Ma H, Zhang S, Zhao H (2020) Estimating the case fatality ratio of the COVID-19 epidemic in China. medRxiv:2020.2002.2017.20023630. https://doi. org/10.1101/2020.02.17.20023630

5. Petrilli CM, Jones SA, Yang J, Rajagopalan H, O'Donnell L, Chernyak Y, Tobin KA, Cerfolio RJ, Francois F, Horwitz LI (2020) Factors associated with hospital admission and critical illness among 5279 people with coronavirus disease 2019 in New York City: prospective cohort study. BMJ 369:m1966. https://doi. org/10.1136/bmj.m1966

6. Heinrich F, Sperhake JP, Heinemann A, Mushumba H, Lennartz M, Norz D, Glatzel M, Lutgehetmann M, Puschel K (2020) Germany's first COVID-19 deceased: a 59-year-old man presenting with diffuse alveolar damage due to SARS-CoV-2 infection. Virchows Arch 477(3):335-339. https://doi.org/10.1007/ s00428-020-02872-y

7. Borczuk AC, Salvatore SP, Seshan SV, Patel SS, Bussel JB, Mostyka M, Elsoukkary S, He B, Del Vecchio C, Fortarezza F, Pezzuto F, Navalesi P, Crisanti A, Fowkes ME, Bryce CH, Calabrese F, Beasley MB (2020) COVID-19 pulmonary pathology: a multi-institutional autopsy cohort from Italy and New York City. Mod Pathol 33(11):2156-2168. https://doi.org/10.1038/ s41379-020-00661-1

8. Maiese A, Manetti AC, La Russa R, Di Paolo M, Turillazzi E, Frati P, Fineschi V (2020) Autopsy findings in COVID-19-related deaths: a literature review. Forensic Sci Med Pathol. https://doi. org/10.1007/s12024-020-00310-8

9. Wichmann D, Sperhake JP, Lutgehetmann M, Steurer S, Edler C, Heinemann A, Heinrich F, Mushumba H, Kniep I, Schroder AS, Burdelski C, de Heer G, Nierhaus A, Frings $\mathrm{D}$, Pfefferle S, Becker H, Bredereke-Wiedling $\mathrm{H}$, de Weerth A, Paschen HR, Sheikhzadeh-Eggers S, Stang A, Schmiedel $\mathrm{S}$, Bokemeyer C, Addo MM, Aepfelbacher M, Puschel K, Kluge S (2020) Autopsy findings and venous thromboembolism in patients with COVID-19: a prospective cohort study. Ann Intern Med 173(4):268-277. https://doi.org/10.7326/ M20-2003

10. The Lancet $\mathrm{H}$ (2020) COVID-19 coagulopathy: an evolving story. Lancet Haematol 7(6):e425. https://doi.org/10.1016/S23523026(20)30151-4

11. Centers for Disease Control and Prevention (2021) Emerging SARS-CoV-2 variants. https://www.cdc.gov/coronavirus/2019ncov/more/science-and-research/scientific-brief-emerging-varia nts.html. Accessed 21.02.2021

12. European Centre for Disease Prevention and Control (2020) Risk related to spread of new SARS- CoV-2 variants of concern in the EU/EEA. https://www.ecdc.europa.eu/sites/default/files/docum ents/COVID-19-risk-related-to-spread-of-new-SARS-CoV-2variants-EU-EEA.pdf. Accessed 21.02.2021

13. Davies NG, RCB, Jarvis CI, Kucharski AJ, Munday J, CABP, Russell TW, Tully DC, Abbott S, Gimma A, Waites W, Wong KLM, van Zandvoort K, CMMID COVID-19 Working Group, Eggo RM, Funk S, Jit M, Atkins KE, Edmunds WJ (2020) Estimated transmissibility and severity of novel SARSCoV-2 Variant of Concern 202012/01 in England. Accessed 21.02 .2021 
14. V'Kovski P, Kratzel A, Steiner S, Stalder H, Thiel V (2020) Coronavirus biology and replication: implications for SARS-CoV-2. Nat Rev Microbiol. https://doi.org/10.1038/s41579-020-00468-6

15. Kissler SM, Fauver JR, Mack C, Tai CG, Breban MI, Watkins AE, Samant RM, Anderson DJ, Ho DD, Grubaugh ND, Grad YH (2021) Densely sampled viral trajectories suggest longer duration of acute infection with B.1.1.7 variant relative to non-B.1.1.7 SARS-CoV-2. medRxiv:2021.2002.2016.21251535. https://doi. org/10.1101/2021.02.16.21251535

16. Davies NG, Jarvis CI, Edmunds WJ, Jewell NP, Diaz-Ordaz K, Keogh RH (2021) Increased hazard of death in community-tested cases of SARS-CoV-2 Variant of Concern 202012/01. medR xiv:2021.2002.2001.21250959. https://doi.org/10.1101/2021.02. 01.21250959

17. Nicholas Davies SA, Barnard RC, Jarvis CI, Kucharski AJ, Munday JD, Pearson CAB, Russell TW, Tully DC, Washburne AD, Wenseleers T, Gimma A, Waites W, Wong KLM, van Zandvoort K, Silverman JD, CMMID COVID-19 working group, Eggo RM, Funk S, Jit M, Atkins KE, Edmunds WJ (2021) Estimated transmissibility and severity of novel SARS-CoV-2 Variant of Concern 202012/01 in England. https://cmmid.github.io/topics/covid19/ uk-novel-variant.html. Accessed 21.02.2021

18. Deutschen Gesellschaft für Rechtsmedizin (2017) Die rechtsmedizinische Leichenöffnung. https://www.awmf.org/uploads/ tx_szleitlinien/054-0011_S1_Die-rechtsmedizinische_Leichenoef fnung_2018-02.pdf. Accessed 21.02.2021

19. Hanley B, Lucas SB, Youd E, Swift B, Osborn M (2020) Autopsy in suspected COVID-19 cases. J Clin Pathol 73(5):239-242. https://doi.org/10.1136/jclinpath-2020-206522

20. Heinrich F, Meissner K, Langenwalder F, Puschel K, Norz D, Hoffmann A, Lutgehetmann M, Aepfelbacher M, Bibiza-Freiwald E, Pfefferle S, Heinemann A (2021) Postmortem stability of SARS-CoV-2 in nasopharyngeal mucosa. Emerg Infect Dis 27(1). https://doi.org/10.3201/eid2701.203112

21. Nörz D, Grunwald M, Olearo F, Fischer N, Aepfelbacher M, Pfefferle S, Lütgehetmann M (2021) Evaluation of a fully automated high-throughput SARS-CoV-2 multiplex qPCR assay with buildin screening functionality for DelHV69/70- and N501Y variants such as B.1.1.7. medRxiv:2021.2002.2012.21251614. https://doi. org/10.1101/2021.02.12.21251614

22 Pfefferle S, Reucher S, Nörz D, Lütgehetmann M (2020) Evaluation of a quantitative RT-PCR assay for the detection of the emerging coronavirus SARS-CoV-2 using a high throughput system. Eurosurveillance 25(9):2000152. https://doi.org/10.2807/ 1560-7917.ES.2020.25.9.2000152

23. Pfefferle S, Gunther T, Kobbe R, Czech-Sioli M, Norz D, Santer R, Oh J, Kluge S, Oestereich L, Peldschus K, Indenbirken D, Huang J, Grundhoff A, Aepfelbacher M, Knobloch JK, Lutgehetmann M, Fischer N (2021) SARS Coronavirus-2 variant tracing within the first Coronavirus Disease 19 clusters in northern Germany. Clin Microbiol Infect 27(1):130 e135-130 e138. https://doi. org/10.1016/j.cmi.2020.09.034

24. Gunther T, Czech-Sioli M, Indenbirken D, Robitaille A, Tenhaken P, Exner M, Ottinger M, Fischer N, Grundhoff A, Brinkmann MM (2020) SARS-CoV-2 outbreak investigation in a German meat processing plant. EMBO Mol Med 12(12):e13296. https://doi.org/ 10.15252/emmm.202013296

25. Li H (2018) Minimap2: pairwise alignment for nucleotide sequences. Bioinformatics 34(18):3094-3100. https://doi.org/ 10.1093/bioinformatics/bty191

26. Erik Garrison GM (2012) Haplotype-based variant detection from short-read sequencing. q-bio.GN. arXiv:1207.3907
27. Wang K, Li M, Hakonarson H (2010) ANNOVAR: functional annotation of genetic variants from high-throughput sequencing data. Nucleic Acids Res 38(16):e164. https://doi.org/10.1093/nar/ gkq603

28. Shu Y, McCauley J (2017) GISAID: global initiative on sharing all influenza data - from vision to reality. Euro Surveill 22(13). https://doi.org/10.2807/1560-7917.ES.2017.22.13.30494

29. Kniep I, Lutter M, Ron A, Edler C, Puschel K, Ittrich H, Heller M, Heinemann A (2020) Postmortem imaging of the lung in cases of COVID-19 deaths. Radiologe 60(10):927-933. https://doi.org/ 10.1007/s00117-020-00733-y

30. Miyazawa M (2020) Immunopathogenesis of SARS-CoV-2-induced pneumonia: lessons from influenza virus infection. Inflamm Regen 40:39. https://doi.org/10.1186/s41232-020-00148-1

31. Goshua G, Pine AB, Meizlish ML, Chang CH, Zhang H, Bahel P, Baluha A, Bar N, Bona RD, Burns AJ, Dela Cruz CS, Dumont A, Halene S, Hwa J, Koff J, Menninger H, Neparidze N, Price C, Siner JM, Tormey C, Rinder HM, Chun HJ, Lee AI (2020) Endotheliopathy in COVID-19-associated coagulopathy: evidence from a single-centre, cross-sectional study. Lancet Haematol 7(8):e575e582. https://doi.org/10.1016/S2352-3026(20)30216-7

32. Varga Z, Flammer AJ, Steiger P, Haberecker M, Andermatt R, Zinkernagel AS, Mehra MR, Schuepbach RA, Ruschitzka F, Moch H (2020) Endothelial cell infection and endotheliitis in COVID-19. Lancet 395(10234):1417-1418. https://doi.org/10. 1016/S0140-6736(20)30937-5

33. Edler C, Schroder AS, Aepfelbacher M, Fitzek A, Heinemann A, Heinrich F, Klein A, Langenwalder F, Lutgehetmann M, Meissner K, Puschel K, Schadler J, Steurer S, Mushumba H, Sperhake JP (2020) Dying with SARS-CoV-2 infection-an autopsy study of the first consecutive 80 cases in Hamburg, Germany. Int J Legal Med 134(4):1275-1284. https://doi.org/10.1007/s00414-020-02317-w

34. Solomon IH, Normandin E, Bhattacharyya S, Mukerji SS, Keller K, Ali AS, Adams G, Hornick JL, Padera RF Jr, Sabeti P (2020) Neuropathological features of Covid-19. N Engl J Med 383(10):989-992. https://doi.org/10.1056/NEJMc2019373

35. Matschke J, Lütgehetmann M, Hagel C, Sperhake JP, Schröder AS, Edler C, Mushumba H, Fitzek A, Allweiss L, Dandri M, Dottermusch M, Heinemann A, Pfefferle S, Schwabenland M, Sumner Magruder D, Bonn S, Prinz M, Gerloff C, Püschel K, Krasemann S, Aepfelbacher M, Glatzel M (2020) Neuropathology of patients with COVID-19 in Germany: a post-mortem case series. Lancet Neurol 19(11):919-929. https://doi.org/10.1016/S1474-4422(20) 30308-2

36. Glatzel M, Hagel C, Matschke J, Sperhake J, Deigendesch N, Tzankov A, Frank S (2021) Neuropathology associated with SARS-CoV-2 infection. Lancet 397(10271):276. https://doi.org/ 10.1016/S0140-6736(21)00098-2

37. Centers for Disease Control and Prevention (2021) Evidence used to update the list of underlying medical conditions that increase a person's risk of severe illness from COVID-19. https://www. cdc.gov/coronavirus/2019-ncov/need-extra-precautions/evidencetable.html. Accessed 21.02.2021

38. Wolfel R, Corman VM, Guggemos W, Seilmaier M, Zange S, Muller MA, Niemeyer D, Jones TC, Vollmar P, Rothe C, Hoelscher M, Bleicker T, Brunink S, Schneider J, Ehmann R, Zwirglmaier K, Drosten C, Wendtner C (2020) Virological assessment of hospitalized patients with COVID-2019. Nature 581(7809):465469. https://doi.org/10.1038/s41586-020-2196-x

39. Meinhardt J, Radke J, Dittmayer C, Franz J, Thomas C, Mothes R, Laue M, Schneider J, Brunink S, Greuel S, Lehmann M, Hassan O, Aschman T, Schumann E, Chua RL, Conrad C, Eils R, 
Stenzel W, Windgassen M, Rossler L, Goebel HH, Gelderblom HR, Martin H, Nitsche A, Schulz-Schaeffer WJ, Hakroush S, Winkler MS, Tampe B, Scheibe F, Kortvelyessy P, Reinhold D, Siegmund B, Kuhl AA, Elezkurtaj S, Horst D, Oesterhelweg L, Tsokos M, Ingold-Heppner B, Stadelmann C, Drosten C, Corman VM, Radbruch H, Heppner FL (2021) Olfactory transmucosal SARS-CoV-2 invasion as a port of central nervous system entry in individuals with COVID-19. Nat Neurosci 24(2):168-175. https:// doi.org/10.1038/s41593-020-00758-5

40. Tomita H, Yamashiro T, Ikeda H, Fujikawa A, Kurihara Y, Nakajima Y (2016) Fluid collection in the retropharyngeal space: a wide spectrum of various emergency diseases. Eur J Radiol 85(7):1247-1256. https://doi.org/10.1016/j.ejrad.2016.04.001

41. Burger L (2020) Germany reports first case of coronavirus variant spreading in Britain. Reuters. https://www.reuters.com/artic
le/us-health-coronavirus-germany-variant-idUSKBN28Y1LO. Accessed 21.02.2021

42. Robert Koch Insitute (2021) Bericht zu Virusvarianten von SARSCoV-2 in Deutschland, insbesondere zur Variant of Concern (VOC) B.1.1.7. https://www.rki.de/DE/Content/InfAZ/N/Neuar tiges_Coronavirus/DESH/Bericht_VOC_05022021.pdf?_blob= publicationFile. Accessed 21.02.2021

Publisher's note Springer Nature remains neutral with regard to jurisdictional claims in published maps and institutional affiliations. 